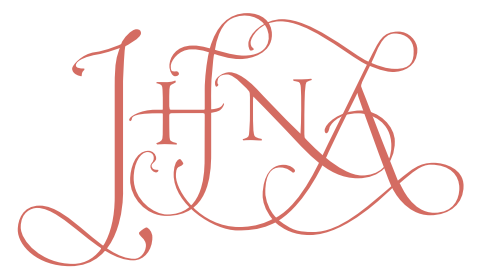

JOURNAL OF HISTORIANS OF NETHERLANDISH ART

Volume 8, Issue 2 (Summer 2016)

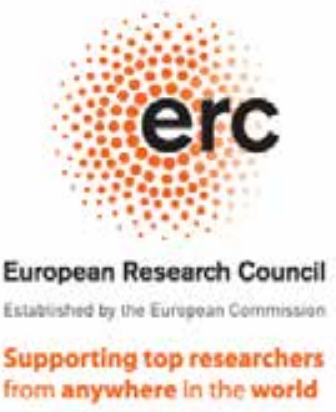

\title{
Sublime Still Life: On Adriaen Coorte, Elias van den Broeck, and the Je ne sais quoi of Painting
}

Hanneke Grootenboer

hanneke.grootenboer@hoa.ox.ac.uk

Recommended Citation:

Hanneke Grootenboer, "Sublime Still Life: On Adriaen Coorte, Elias van den Broeck, and the Je ne sais quoi of Painting," JHNA 8:2 (Summer 2016), DOI: 10.5092/jhna.2016.8.2.10

Available at https://jhna.org/articles/sublime-still-life-adriaen-coorte-elias-van-den-broeck-je-nesais-quoi-painting/

Published by Historians of Netherlandish Art: https://hnanews.org/

Republication Guidelines: https://jhna.org/republication-guidelines/

Notes: This PDF is provided for reference purposes only and may not contain all the functionality or features of the original, online publication. This PDF provides paragraph numbers as well as page numbers for citation purposes.

ISSN: 1949-9833 


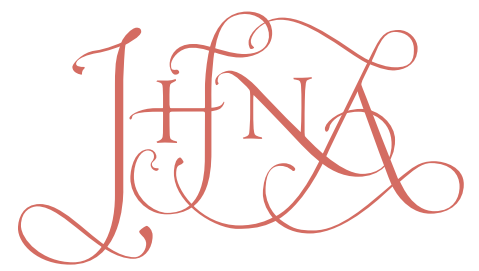

\section{SUBLIME STILL LIFE: ON ADRIAEN COORTE, ELIAS VAN DEN BROECK, AND THE JE NE SAIS QUOI OF PAINTING}

\section{Hanneke Grootenboer}

This paper explores the ways in which Adriaen Coorte (1665-1707) in his still lifes presents philosophical reflections on sublimity. I argue that throughout his oeuvre Coorte, despite the unusually small size of his works (often not much larger than a postcard), can be seen searching for the limits of painting. Special attention is given to the unconventional way in which he animates his fruits and shells, presenting them as if they are actors in an indefinable place, and the rather extreme contradictions in dimension and scale he employs. I conclude by referring to another type of sublimity in painting in a truly genuine fusion of painting and collage in a forest piece by Elias van den Broeck. D0I: 10.5092/jhna.2016.8.2.10

The Beautiful is the perfection, the Sublime the suspension, of the comparing Power. -Coleridge

\section{The Sublime Is Suspension}

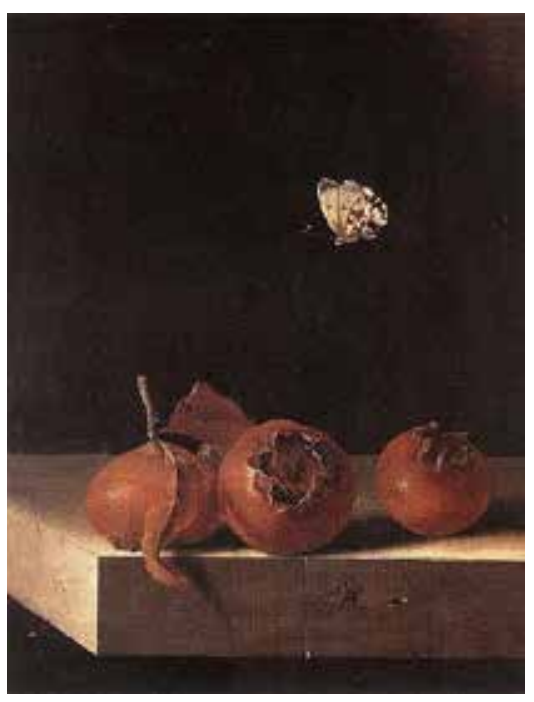

Fig. 1 Adriaen Coorte, Still Life with Medlars, ca. 1693-95, oil on paper on cardboard, $26.9 \times 20.4 \mathrm{~cm}$. The Netherlands, Private Collection (artwork in the public domain)

At the beginning of the 1690s, Adriaen Coorte painted a small still-life scene of three medlars on a stone ledge (fig. 1). A small brown butterfly flutters over the fruits, its astute feelers conspicuously poised against the black backdrop. In contrast to the nocturnal darkness stretching out behind 
it, the stone ledge is bathed in a shaft of early morning light falling through a narrow opening that splits the otherwise closed curtains. The little butterfly seems to have sought out the bright light, having just come into its narrow beam. Chipped here and there at its edges, the ledge is adorned only by Coorte's signatory intertwining initials and a single, surprisingly straight crack. That is all there is. The tiny picture is utterly unassuming, even more so considering that it is slightly smaller than an A4 sheet of paper. Such modesty is surprising in light of its historical position at the tail end of the monumental seventeenth-century still-life tradition, which was given over to excessive expositions of exotic foods and expensive collector's items that were turned into genuine spectacles by Jan Davidsz de Heem, Jan van Huysum, and other artists. Juxtaposed with those celebrations of the senses, Coorte's scene is devoid of any kind of visual extravagance: there are no bright screaming colors, no towering heaps of foodstuffs, no shimmer or shine. Why should we even look at this painting in the first place? With its understated dimensions and muted color palette it seems almost apologetic about the little it has to offer. The fact that this simple scene, although rendered in oil, is painted on cheap paper glued to cardboard rather than on canvas or panel (for his paintings the artist often used a page from an account book no longer in use) only adds to its apparent humbleness. Compared to de Heem's or van Huysum's exuberant and noisy compositions, Coorte's is small, plain, and somehow very silent.

2 And yet its simplicity does not make it any easier for us as viewers to take it in. Unlike the theatrical and hyped excitement offered by de Heem and van Huysum-so bombastically performing for us as spectators-we have to make an effort to actually see Coorte's painting. We have to move closer and bend toward it in order to study the neatness of the fruit, the liveliness of the ordinary butterfly. It is only then that we can start to feel ourselves lost in this little painting; only then that we are startled by the sudden thought that there might, in fact, be more in this image than is actually being offered to us; and only then that we see that the perpendicular crack in the ledge does not stand alone but is part of a fundamental fissure that cuts invisibly through the image's darkness, sharply defining the butterfly's precise position to its right by being a hair's distance from its feelers. Where is the little butterfly going anyway? Is it attempting to escape from the yawning darkness surrounding it, a void filled with total nothingness, by dragging itself to the light?

If we bend toward it and peer closely, what is otherwise quite a sweet picture turns into a rather disconcerting image. The medlars on the ledge's edge slowly begin to lose their familiarity as fruits we might pick up and eat. They do not lie there quietly but threaten to plunge into the depths of the image, as if hanging from invisible threads. Although a vague indication of the stand underneath the tabletop offers some sense of stability, we are not sure how much more darkness surrounds this little place, which appears as if it were a corner not of a table but of the world itself, with the universe expanding around it. This is no ordinary kitchen table. Where exactly are we?

4 Coorte seems to have been genuinely interested in issues of suspension, balance, and approximation. Some early pieces from the late 1680s depict fruits or nuts dangling from a thread beneath hovering tree sprigs. The suspended branches were eventually displaced by a butterfly, but later even that transformative insect disappeared, and only darkness stretched out behind Coorte's delicately painted fruits and shells. ${ }^{2}$ Whereas Coorte's life is largely shrouded in mystery, his work enjoyed considerable attention from a steady stream of clients, as we know from the many detailed mentions of his work in inventories; these buyers were almost exclusively from the vicinity 
of the city of Middelburg in the province of Zeeland. It is likely that he served as an apprentice in the studio of Amsterdam painter of birds Melchior d'Hondecouter, as Coorte almost exactly copied one of the older painter's landscapes with a pelican and other birds, now in the Ashmolean Museum in Oxford. Another likely influence was forest pieces, which were often used as study material and conversation pieces by artists such as Otto Marseus van Schrieck and Elias van den Broeck. $^{3}$

Most of the sixty-odd paintings known to have been made by Coorte follow a pattern of composition that must have been commercially lucrative, as he repeated it again and again: a stone ledge, very similar to what is featured in our image, that shows fruits or other objects laid out on its edge. Grapes, spears of asparagus, peaches, apricots, nuts, black currants, and even shells are presented to us on the same stone ledge as if they are there for our taking. However, most of these offerings reach far over the edge, as if about to tumble off. For instance, in a still life with gooseberries, a spray of the beautifully translucent fruits hangs over the edge in precarious balance (1693, Germany, private collection). Whereas the little earthenware test containing wild strawberries, a common feature in Coorte's oeuvre, stands firmly on its little legs, there is always something that undermines the overall stability: a sprig dangerously hanging over the edge, or a loose strawberry that has rolled to a full stop just before it. In addition, whereas most modest Dutch still lifes, such as the breakfast pieces by Pieter Claesz and Willem Heda (said to have been Coorte's model or inspiration), show tabletops spanning canvases that are wider than they are tall, the portrait-style format of most of Coorte's pictures allows just a corner of the table to show and thus emphasizes the void surrounding it on two sides. Paul Claudel noted in his essay of the 1930s on Dutch painting that the breakfast pieces of Claesz and Heda always contain elements that were about to fall; they present us with "an arrangement in imminent danger of disintegration; it is something at the mercy of time." ${ }^{4}$ Simon Schama later interpreted the lack of balance in these still-life compositions as a symptom of the "embarrassment of riches" felt by Dutch Calvinist merchants when contemplating the wealth of their possessions as citizens of a young Republic constantly at war.

Claudel's and Schama's brilliant readings are very apt for larger still lifes, such as the breakfast pieces mentioned above or for the messy compositions in which very expensive objets d'art are thrown together with costly exotic fruits, but they do not yield much insight into the tiny pictures by Coorte, which offer us something very specific that remains hard to define. Coorte's precious fruits and vegetables can be seen as vanitas images or interpreted in a religious or spiritual context, whereby, for instance, the meticulously painted medlars celebrate nature as a second Bible, and the butterfly can be considered a symbol of Christian resurrection. ${ }^{6}$ Like Schama's Calvinist perspective, such conventional iconographic readings may give plausible explanations for the paintings' subject matter, but they do not account for the specificity of Coorte's work, which results from extremes in terms of size, composition, and simplification. It is Coorte's unconventionality that I would like to explore.

$7 \quad$ Seen in the larger context of Coorte's highly stylized oeuvre, Still Life with Medlars (and other paintings like it) reveals an astonishing vastness at the heart of its diminutive composition. If anything, the blackness projected behind the innocent butterfly signifies immeasurability, and the plain, sharply outlined beauty of the medlars further confirms the void's infigurability. 
Something is larger than life here, or is at least too large for the tiny picture to contain: a kind of monumentality - for lack of a better term - that is at odds with the composition's smallness and sophistication. What it is that captures and astonishes us is difficult to say. Is it the suspension, the subtle threat of the medlars rolling off the edge, the utter loneliness of the butterfly pictured against the void, making its course toward the unknown? Coorte's contemporaries may have called this elusive quality the je ne sais quoi of his paintings, and his clients or commissioning patrons must have recognized an unsettling quality that nonetheless fascinated them and urged them to return to these images time and again. Coorte's paintings were often part of collections as pairs or a series of three-one collector possessing no fewer than fourteen of his paintings. The artist's clients and their visitors would probably have studied the small pictures quite closely, and we can imagine them experiencing what art theorist Samuel van Hoogstraten (a contemporary of Coorte's) identified as an "inexpressible joy" as well as a "terrifyingly confused inner struggle" when confronted with the ik en weet niet en wat of such a work.

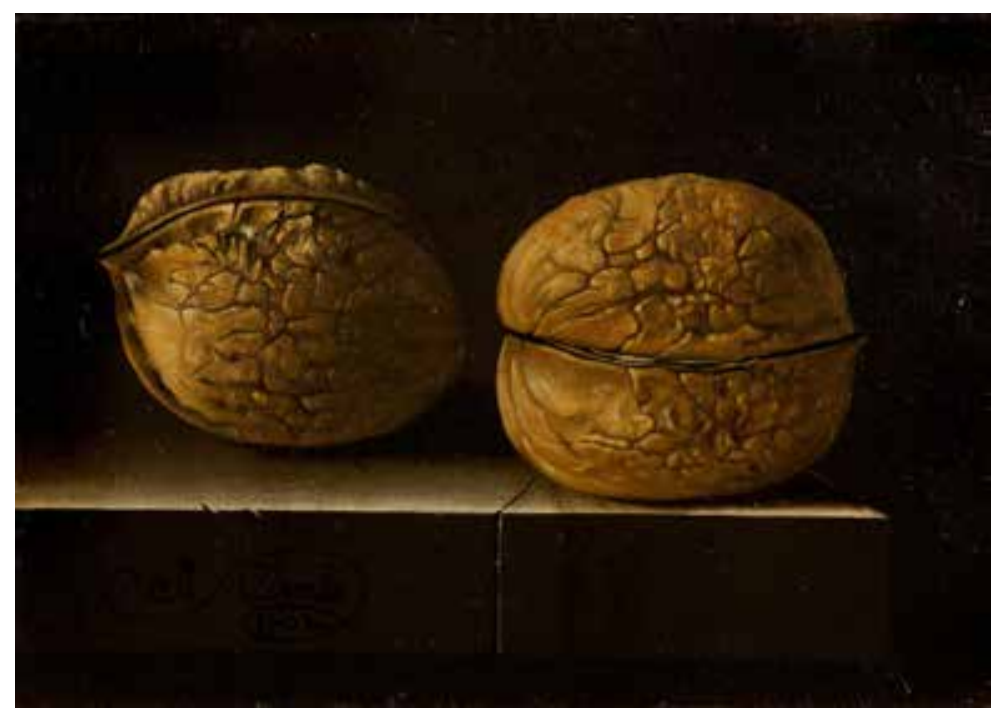

Fig. 2 Still Life with Two Walnuts, 1702, oil on paper on cardboard, $10.9 \times 15.6 \mathrm{~cm}$. Budapest, Szépmüvészeti Muzeum (artwork in the public domain; photo: @ Budapest, Szépmürvészeti Muzeum)

Another example further supports Coorte's interest in dimensions, and in particular the extent to which little pictures of small objects seem to prompt an enlarging effect upon the viewer when s/he bends over or toward them to take a closer look. One of the smallest paintings in his oeuvre is Still Life with Two Walnuts from 1702 (fig. 2). Painted on paper glued to cardboard, its dimensions are $10.9 \times 15.6 \mathrm{~cm}$, once again akin to those of a postcard. Usually Coorte rendered nuts on a lifelike scale but in this extraordinary image, we are faced by what appear to be giant walnuts placed on the ubiquitous ledge and surrounded by deep darkness. Whereas the walnut on the right lies on its side, its two halves equally visible, the one on the left has been turned so that one of its halves faces toward us so that we can view it whole; it is placed a little further from the ledge's edge, as if it has rolled backward. We recognize the pattern and motifs from Still Life with Medlars: the chipped edge, the signature, the remarkably straight crack running perpendicular down the ledge, and the utter darkness surrounding this simple display. But though the composition has been repeated, something seems unhinged. Obviously, the walnuts are too large for the boxlike space in which they find themselves. Although not quite bursting out of the picture's frame, they are clearly too closely cropped. Or is it that we are too close? The further we zoom out, the larger the walnuts seem to become: it is as if they are growing, expanding in their cavelike 
space. Despite the miniature format of the picture, their dimensions are grossly exaggerated, even grotesque. We can imagine Coorte painting this dark scene with his nose almost touching the paper, constantly moving his head and his gaze from the painted scene to its real-life model-he might even have accidentally brushed his eyelashes over the nuts. In the age of the microscope and the telescope, instruments that opened up a visible world inaccessible to the naked eye, these walnuts come too close: too close to the picture plane (there is hardly any suggestion of depth beyond the width of the nut), too close to the edge, too close to the eye.

9 What is happening here? We viewers are just as much in the dark as the nuts as we study their beige shells, which vaguely recall skulls or brains. They are shut like clams, revealing not much more than their exteriors, and yet they assert themselves, push themselves forward. This is not just a study of the appearance of nuts-or a phenomenology of nuts in paint-but an attempt to approach them, to get under their skins, to get closer and closer to them. ${ }^{8}$ Where do Coorte's gaze and brush end, and where does the darkness of imperceptibility begin? Perhaps even more than in Still Life with Medlars, Coorte's walnuts, in their tight, almost shrinking frame, have achieved a sense of sublimity-yet they have done so not through a grandiose and pompous spectacle, but in the smallest way possible. Transcending accepted standards and measures, the painting stages a clash of two opposing forces: the size of the nuts is blown up while the space of the image is dramatically diminished.

10 About eighty years after this painting was finished, Kant would define the sublime as "that which stands above the edges of an already full-measure," and indeed, paradoxically, there is almost too much in this scene-spilling over, it enacts a kind of internal excess of representation as such. In contrast to the traditional excessively baroque compositions of de Heem and van Huysum-with bouquets of flowers bursting out of their vases, bright red lobsters balancing on heaps of ripe fruits, mouthwatering melons about to slide off their plates, and oysters dripping their liquid so convincingly you can almost smell them-Coorte's paintings seem to have turned the tables, moving from overwhelming visibility to the uneasy, caged close-up that reveals the invisibility that exists between us and what surrounds us.

11 What exactly do we "see" in this small picture? Here we seem to have arrived at a threshold between a handful of highly articulate natural things (apart from some tests and china bowls holding strawberries, Coorte exclusively painted natural objects) and an inarticulate darkness. Are we supposed to remain like this, in a posture of seeing that basically forces our noses to touch the painted walnuts as we peer into the void that stretches out behind them? Is something revealed to us about walnuts, or about painting as such? Likewise, in Still Life with Medlars, are we supposed to be like the butterfly, a speck eternally suspended in a black universe? The je ne sais quoi of these paintings is something more than an indefinable "grace," as van Hoogstraten would have it, as grace is hardly applicable to the walnuts.

12 I would like to suggest that however unpretentious these pictures of medlars and walnuts might be, their inexplicable vastness evokes Blaise Pascal's meditations on where we, as human beings, find ourselves in the universe. Inspired by perspectival painting, among other things, Pascal places us between the dazzling firmament sparkling with distant stars and the ultimate minuteness of the atom, between, in mathematical terms, the infinitely large and the infinitely small. If 
we imagine, Pascal writes, the imperceptibility of our body as a speck within the universe's infinity, we can equally imagine our body's colossal proportions when compared to the nothingness beyond our reach in, for instance, microscopic elements. "I want to make us see within [nature's microcosm] a new abyss," Pascal writes in his Pensées, and not only does he show us this abyss, he shows us our position in it. We are "suspended between the two gulfs of the infinite and the void" at "a mid-point between nothing and everything ... equally incapable of seeing the nothingness from where [we] came and the infinite in which he is covered." "Let us lose ourselves in these wonders," Pascal continues, "which are as startling in their minuteness as others are in the vastness of their size." Reformulating this middle point between all and nothing in the fragmentary notes grouped under the title "Vanity," Pascal claims that perspectival painting can somehow designate such a middle point between two infinities, two extremes, or two versions of immeasurability..$^{10}$ Linear perspective is a geometrical method that creates a sense of recession and depth on a two-dimensional picture plane by placing the painting's surface at the intersection of converging lines running from the point of view outside the painting and from the vanishing point within the painting. If drawn out, a perspectival configuration looks like two cones meeting at their bases, and this invisible network of perfect proportion underlies all pictorial representation. As it places man on a defined, plotted locus between the point of view and the vanishing point, painting therefore gives us a handle to hold on to, a sort of blueprint that situates us between the infinitely large and the infinitely small, as it directs our gaze from the point of view toward the vanishing point-sometimes termed the infinity point-that continues to recede into a depth that is beyond contemplation.

13 While Coorte's paintings should not be regarded as illustrations of Pascal's theory, they do possess a kind of abyssal quality related to the issues of suspension and in-betweenness taken up by Pascal. From the midpoint that is our position, the awareness of the two extremes that condition the painting fills us with a mixture of terror and wonder, a feeling that the Dutch art theorist Franciscus Junius calls "astonished extasie [sic]" or "astonishment of wonder." ${ }^{11}$ Junius describes how the strong feelings of inexpressible joy and terror evoked by certain paintings render even the most eloquent speaker speechless. Definitions of the indefinable je ne sais quoi of paintings differ, yet most accounts of the seventeenth century and beyond agree that sublimity is characterized by a fusion of opposed forces in a single painting. André Félibien writes that "this je ne sais quoi to which we so often refer yet which we describe so poorly is like the secret knot that binds together these two parts of the body and soul," ${ }^{12}$ while Dominique Bouhours terms the inexpressible quality the "marvelous" and claims that it results from "the union of two thoughts and two terms that seem contrary and incompatible." ${ }^{13}$ Van Hoogstraten writes in his introductionof the "truly great" (waarlijk groots) "terrifyingly confused inner struggle," while Pascal posits that the two infinities fill us with wonder and horror at the same time.

14 In this essay I am less interested in a precise definition of this indefinable sublimity and more in the extent to which it was articulated in painting prior to its being put into words by later theoretical treatises. ${ }^{14}$ Indeed, I would like to suggest that Coorte's highly unusual still lifes-which diverge from the Netherlandish still-life tradition with regard to their technique, size, subject matter, color palette, and general lack of theme-visualize the indefinable and the inexpressible so characteristic of sublimity more accurately than words have ever been able to articulate. ${ }^{15}$ The phrase je ne sais quoi/ik en weet niet en wat (note the individualization of the attempt by the use 
of $j e$ or $i k$ ) sums up the discrepancy between this moment of "astonished extasie" that we experience based on something we find in painting, and our failure to translate that finding into words. Specifically, I would like to take this notion of a fusion of incompatible forces as a starting point. Most accounts agree that the sublime is not just the visualization of the unrepresentable but also painting's attempt to reach beyond its own safe limits-just as Coorte's medlars seem to approach the table's edge as if intending to fall down. ${ }^{16}$ As we will see, painting in general and Coorte's miniature tableaus in particular seem to want to go beyond the order of painting, beyond what can be properly defined as painting. Not only have his oil paintings shrunk to the dimensions of outsized miniatures but within the modest space at his disposal, Coorte adds so few things that his creations can barely be called still lifes. And, paradoxically, the objects that do appear are too large for the space.

15 In the preface to his French translation of Peri Hypsous, Nicolas Boileau emphasizes Longinus's distinction between a sublime, elevated style and a substantive sublime that can be very specific and can be shown using a simple style as well as something more grand. In particular in section nine, starting from the idea that the effect of an elevated style on an audience is not persuasion but transport, Longinus states that there are five sources of elevated language: great ideas and inspired passion, which are inherent in the sublime, and the formation of figures, noble diction, and composition, which are the products of art. A monumental style is not required: greatness can be found in simplicity as long as it is free from ignoble thoughts; indeed eloquent language is not needed as the bare idea alone is capable of inspiring sublimity. As an example of an image that most perfectly captures his definition of sublimity as "the echo of a great soul" Longinus refers to Ajax's silence in the Underworld in the Odyssey (11.543), which is "great and more sublime than words." ${ }^{17}$ Despite the exquisite rendering of his humble objects, in Coorte's mini-paintings sublimity is not found in the overwhelming and dwarfing power of nature. Unlike, for instance, wild seascapes of flashing lightning bolts and tempestuous skies or scenes of towering mountain peaks reaching into the clouds, the sublime shows itself in absence, in the void, and in minutiae. It is precisely in the infinitesimal, where the opposing forces of shrinkage and inflation are in play, that an inward immensurability rules. Going beyond Longinus's contradictory description that silence can be more sublime than words, Louis Marin aptly identifies the je ne sais quoi as that which is "over-filling," filling something that is already full; it is "what is between the brim and the brimming over of measure, of form." 18

16 I suggest that in Coorte's minimalism the sublime does not show itself as symbolized by something (such as a lightning bolt or an intensely orange sky) but as falling outside the order of representation as such by challenging painting's very form. The sublime makes itself felt not through representation but through presentation, as an instance that carries us away, transports us, brings us to another place; and it does so, if not by breaking through the boundaries that define its own medium or genre, then by tending toward such delineations. As we will see, Coorte's paintings approach their own limitations in an attempt, perhaps, not to overcome them but to push them further, to go beyond them without violating them, and in doing so, they mimic the impact they have on us. For what we experience as sublime is the far thresholdof our own comprehension, indeed, the formlessness of the unexperienced, the unknown. If anything, sublimity delights and horrifies, it stops us in our tracks, it makes us speechless, and in this moment of arrest, it shows us an insight-like lightning, Longinus tells us-that is a glimpse of the unknown revealed to us in 
its entirety; yet exactly what is revealed we do not know..$^{19}$ Although presenting us with a failure of knowledge in a narrow sense, a failure of comprehension, the sublime in painting gives us something thought-provoking that we had not yet been able to think or feel. When painting shows itself to be searching for its own limits, its effect on its audience may go beyond persuasion toward transport, just as Longinus would have it. Rather than just being persuaded by a painting's realism or conceptualization, we may start responding according to it, rather than to it, to the extend thatwe get in tune with it. In the je ne sais quoi of painting, we are confronted with the limitations of expression and articulation, and we recognize in it the limitations of our own thinking as such. As Kant writes, "Sublime is what even to be able to think proves that the mind has a power surpassing any standards of sense." ${ }^{20}$

17 Before saying anything further regarding the extent to which the pictorial sublime mimics not the shortcomings but the potential for thinking about the unknown as such, I will look at how in his tiny creations Coorte manages to touch upon the sublime by searching for the limits of painting. In some of his still lifes, he seems to go beyond the strictly pictorial when he animates his compositions so that they are suggestive of sound and movement. Based on analyses of some of Coorte's works, we will then look into an even greater rupture of painting's limitations in the early modern collages of Coorte's contemporary (and, possibly, partly his inspiration) Elias van der Broeck. Similar to what we have seen in Coorte's paintings, in van der Broeck's work it is again a little butterfly that takes the lead and directs us, not to the light, but to the limit of painting as such. It is perhaps no coincidence that it is through a butterfly, a symbol of transformation and metamorphosis par excellence, that the limits of image-making are opened up and broken down-in a truly modern fashion and, as we will see, achieved at a time when such pictorial transformation was so horrifying that it needed to be destroyed. The next section will deal with some of Coorte's paintings that are particularly involved with animation so as to challenge painting's limits.

\section{Whispering Hazelnuts, Singing Shells}

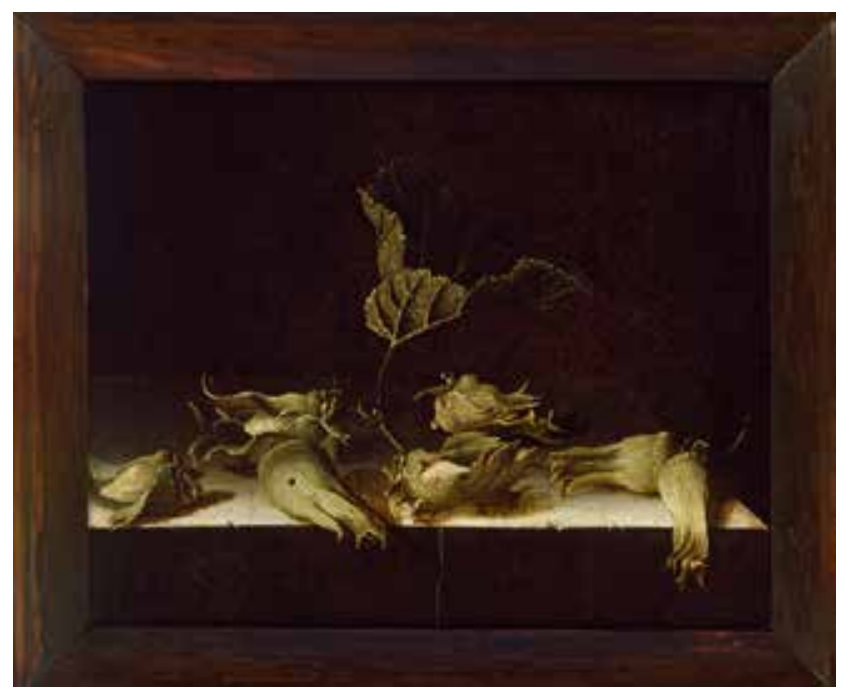

Fig. 3 Adriaen Coorte, Still Life with Hazelnuts, 1696, oil on paper, $16.5 \times 20 \mathrm{~cm}$. Oxford, Ashmolean Museum (artwork in the public domain; photo: () Ashmolean Museum, University of 0xford)

Another tiny picture by Coorte, just a fraction larger than Still Life with Walnuts is a composition with hazelnuts, now it the Ashmolean Museum in Oxford (fig. 3). On the now familiar cracked stone ledge a handful of hazelnuts have been put on display, neatly blanketed in their husks 
against a black background. A leafy twig attached to one of the husks sticks out as if it were a miniature parasol. Only hazelnuts-life-sized this time-occupy this tightly cropped space, nothing more. As with the other Coorte compositions, this pocket-painting insists that we come closer, in order to adjust our gaze to its small dimensions. Only then does this tiny picture come to life. The hazelnuts somehow seem to slowly awaken from a deep sleep: stretching the ends of their husks, as if repressing the impulse to yawn. The longer we look, the more we see that each hazelnut assumes individual traits and turns into a character, playing the role directed by Coorte in the dimmed, pale light of this miniature stage. While the central hazelnut steals the show, proudly presenting its worm-hole as a mark of excellence, two kernels on the right are having an intimate moment, rubbing shoulders as if to greet each other after a long absence. On the left, one hazelnut turns away, quite determined to leave the scene. Has it been called back by the core that approaches it from behind? Are they whispering to one another?

19 Surely, this stilled world of conversing hazelnuts can only be "heard" by the eye of the viewer, and the use of such sensory chiasmus is not unusual in seventeenth-century art and theory, which was deeply influenced by Horace's doctrine of ut pictura poesis and the related assumptions that painting is mute poetry and poetry a speaking painting. ${ }^{21}$ It was generally understood that poetry and painting differ only in substance and mode of imitation and that both have the same end, or rather the same "prospect" (oogenmerck), as Junius wrote in his Dutch translation of De pictura veterum (1641). ${ }^{22}$ The discourse surrounding Horace's doctrine allowed the ascription of contradictory qualities to painting. Junius argues that the "astonishing extasie" not only leaves people speechless, but that this state of excitement is brought about by "beleeving that in these silent lineaments of members they doe see living and breathing bodies $[$ sic $],{ }^{23}$ claiming that the viewer's reaction was most profoundly evoked when a painting came to life, or when it lost its muteness to become a "speaking" painting. The same tongue-tied astonishment Junius describes could occur when the mute outlines not of a human being but of inanimate objects seem to breathe and speak. In addition, painting possessed the capacity not only to animate lifeless images, but also to depict sound. Arnold Houbraken saves his high praise for Jacob van Ruisdael's ability to create landscapes in which we hear how waterfalls splash on rocks and streams bubble up by riverbanks. Whereas Ruisdael depicts nature scenes so lifelike that we see their soundtracks, Coorte departs from this straightforward sublimity by letting us "hear" what would otherwise be a silent scene. If we look at his series of shells, we get a better idea of how Coorte manages to animate his inanimate still lifes by suggesting the presence of sound that would not seem to be there.

20 In the late 1690s, Coorte created a series of pictures of shells taken from the far corners of the world, some deliberately composed as pendants. In his Still Life with Shells of 1698 (fig. 4), a small assemblage of five shells is carefully laid out in a corner dramatically lit as if by theater footlights. A beautifully spotted Cittarium pica, put on its side with its aperture facing us, is flanked by a smaller Trona stercoraria, its slit opening in line with a highly decorative skeleton-shaped shell, its spines carrying it as if it were a multipod insect, with two small shells placed on its either side. As with the hazelnuts, the shells have been given expressive traits and look as if they are taking part in some kind of performance, even as they are merely the vacant remnants of deceased sea creatures. Just as we can assume that the hazelnuts look like they are whispering, we can perceive the shells as singing with different voices in an oddly shaped choir: the Cittarium pica is a low-voiced 


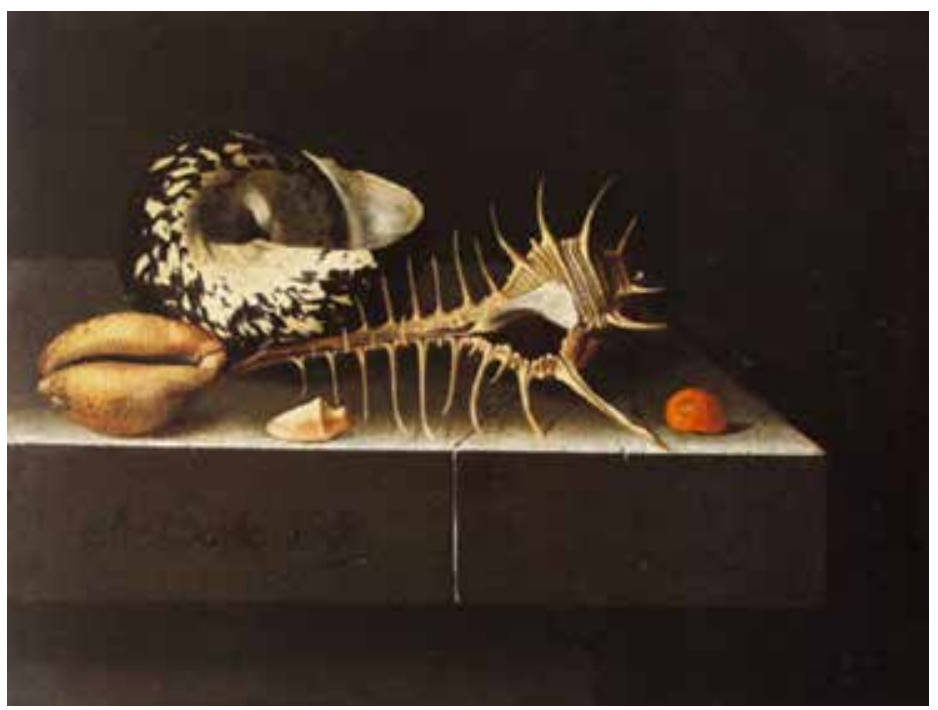

Fig. 4 Adriaen Coorte, Still Life with Shells, 1698, oil on paper, $17.2 \times 22.2 \mathrm{~cm}$. United States, Private Collection (artwork in the public domain)

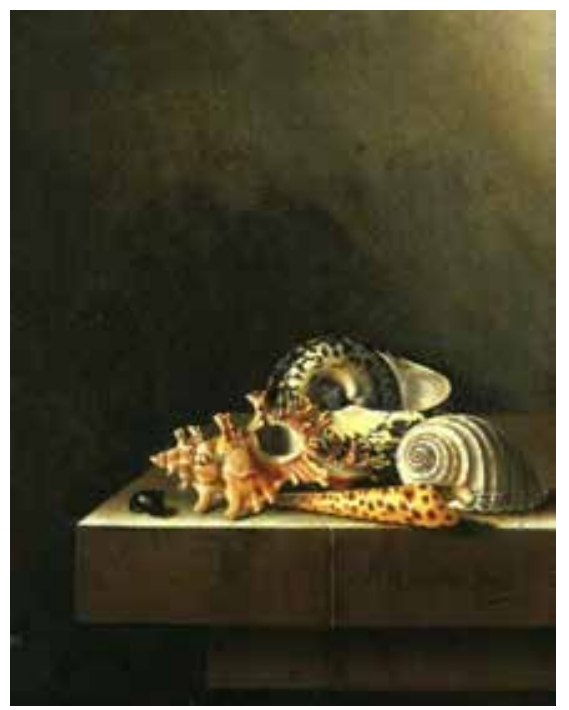

Fig. 5 Adriaen Coorte, Still Life with Shells, 1698, oil on paper on panel, $29.2 \times 22.6 \mathrm{~cm}$. Private Collection (artwork in the public domain)

baritone, the Trona is humming by its side, and the skeleton shell takes the lead. How Coorte manages to create this kind of animation, to the point of evoking a sense of sound in utterly mute objects, remains perhaps the greatest je ne sais quoi. Compared to similar still lifes featuring shells, such as Jan van Kessel's tiny colorful spreads including flowers and insects, Rembrandt's famous etching of a Conus marmoreus, or Balthasar van der Ast's frivolous compositions with delicate wildflowers, Coorte's unembellished display is strikingly different in the attention he gives to each individual shell. Clearly delighted with the artistry and ornamentality that these natural collector's items possess, and fascinated by their astonishing patterns and forms, each perfect in its own variation, Coorte has given them a tiny space to perform their beautiful peculiarities to the fullest. And more. We do not see in these silent lineaments living bodies, as Junius liked to see. What we see is something different: what comes to the fore via their sharp outlines, and the awe-inspiring shapes projected against the black backdrop, is precisely the formlessness of their gaping holes, spiraling deep into the core of their figures. The Still Life with Shells (fig. 5 ) he created in the same year confirms his focus on the dynamic among the shells' capricious forms circulating around their yawning openings. The opening of the slightly differently spotted Cittarium pica is placed so that it pairs up with the hole of the Chicoreus saulii and is flanked, composition-wise, with the spiraling top of white of the Terebra subulata so that a contemplation of spiraling inward and outward is made possible. Huddled together as if they have been forced to find warmth on a cold evening, these shells do not evoke the loud, harmonious a capella musical sound of the earlier picture.

21 Reflecting on painting's eloquence in relation to Kant's distinction between the beautiful and the sublime, Jacques Derrida writes in The Truth in Painting that "from this definition-definition of the beautiful as definable in its contour and of the sublime de-fined as the indefinable for the understanding-you already understand that the sublime is encountered in art less easily than the beautiful, and more easily in 'raw nature." And this is exactly the delicate line between art and raw nature approached by Coorte in taking what is closest in nature to an art work (shells were expensive collector's items) as his sole model and bringing it to life while painting. ${ }^{24}$ With Coorte, 
still life has been shrunk to its smallest dimensions, all the while being turned into a-literalconversation piece.

\section{Early Modern Collage}

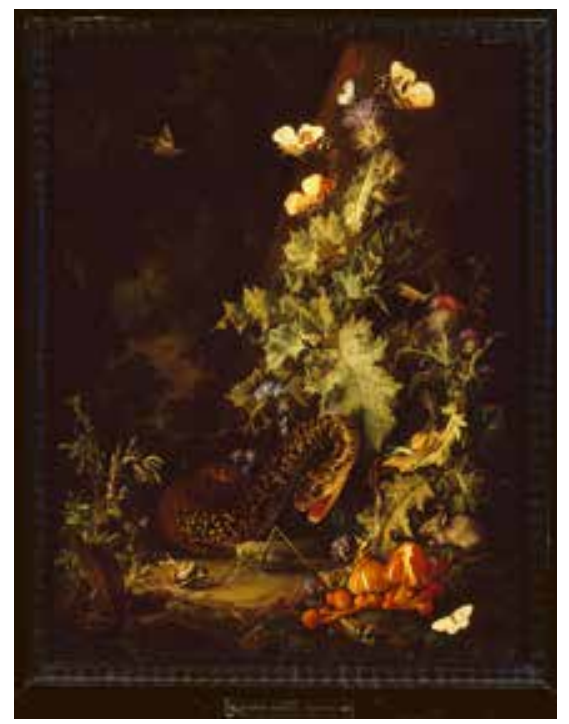

Fig. 6 Elias van den Broeck, Still Life with a Snake, ca. 1695, oil on canvas, $62 \times 53 \mathrm{~cm}$. Oxford, Ashmolean Museum (artwork in the public domain; photo: @ Ashmolean Museum, University of Oxford)

22 Around the same time that Coorte was bending over his little tableaux in or near the city of Middelburg, Elias van den Broeck was working in Antwerp on a series of forest pieces. In one of his creations (fig. 6) we see a nocturnal nature scene in which a snake, his jaws wide open, slithers from behind a prominent thistle to devour a large grasshopper, witnessed by a small mouse sitting near a toadstool, with snails leaving silvery paths behind them. Some moths flutter around the thistle's flower. The composition is a pictorial tour de force: the pregnant moment of the snake about to strike is dramatically lit, but while van der Broeck may well have observed with his own eyes many of the creatures depicted (he might have gone into the woods in the night's darkest hours carrying a lantern over his head), we should not forget that this scenario has been created entirely from the imagination. The narrative tension the artist creates between the threatening snake and the oblivious-looking grasshopper apparently not yet aware of his impending death is quite horrifying. The biological microstructure of this piece of forest lifehas been recorded with microscopic precision, and van der Broeck has magnificently handled his brush so as to render insects and animals with exquisite precision. The species presented here are all meticulously painted in copious detail, as if they had been carefully studied under a magnifying glass. The linear decoration of the snails' houses, the pattern of the snake's skin, and the slashed hoods of the toadstools are all recorded here in an astonishingly realistic fashion. We can feel the waxiness of thistle leaves, a tactility reinforced by the reflection of light on their prickly tips. Evoked even more intensely is the smell of damp soil mixed with the night's breeze, to create what Karin Leonard observes as being typical of van der Broeck's work: a "visual noise or, in fact, a kind of hissing." ${ }^{25}$ We can almost hear the sleek movement of the snake through the mud, the rustling of leaves, the nibbling of insects, the shrieking of the mouse.

23 It is likely that this picture was seriously studied by nature enthusiasts (who we can picture gazing intently through their magnifying glasses to examine the depicted species as if they were their 
real-life counterparts), who may have been affected by the slightly macabre scene. If there is such a thing as early modern horror (a term I borrow from Maria Loh), we have one of its clearest instances here: a creepy scene that gets under your skin. ${ }^{26}$ The baffling realism and the horrific nature of this scene may inspire awe and terror in us as viewers, but that is not, I suggest, where its true sublimity lies. For all its pictorial virtuosity, this image does not at first sight reveal van der Broeck's genuinely innovativegesture whereby he manages to break through the order of representation. Literally leaving pictorial form behind by adding something to the very surface of the painting, van der Broeck elevates part of the image to the level of presentation when, as a finishing touch, he glues to his canvas real butterfly wings, which carefully cover the exact shape of the painted wings of the moths circulating around the thistle's purple flower. By covering meticulously rendered painted wings with actual ones, van der Broeck pushes his extraordinarily realistic painting to its radical limit by deliberately blending the pictorial with the real, in a technique that would only later be equaled in twentieth-century Cubist collage.

24 This brilliant idea cost the artist his reputation. The inhabitants of his native city of Antwerp, having discovered this bizarre merging of the real with the painted, accused him of cheating: after all, parts of the scene that were "in" the painting had not been painted by his hand, and this was, apparently, unforgivable. ${ }^{27}$ The argument made in van der Broeck's favor was that real butterfly wings more accurately show their typical patterns, and that they would survive any painted representation. ${ }^{28}$ This argument was refuted by the material history of the painting: the wings having turned to dust, all that is left of them now are pale spots on the canvas. In any case, the councilors remained unmoved by any defense of van der Broeck, who was forced to leave the city. He never fully recovered from his brilliant streak. Starting anew in Amsterdam as a foreigner, he quarreled with a generous patron, who got so fed up with him that this erstwhile benefactor could no longer bear the sight of his costly forest pieces and sold them to collectors for next to nothing. The market value of van der Broeck's works crashed so spectacularly that he lost the will to live and ended his days sitting idly in his flower garden-perhaps staring at darting butterflies. ${ }^{29}$

25 In light of our discussion of Coorte, the question arises as to the extent of the sublimity of these glued-on wings. If we assume that sublimity lies in the notion of immeasurability and formlessness that we found in the abyssal blackness surrounding Coorte's sparse compositions and in the representation of the unrepresentable-sound and animation-we may find it less in the butterfly wings and more in the mixture of horror and joy that his lively picture evokes. Yet what we find in van der Broeck is painting's ability to surpass itself in its fundamental quest to depict a realistic image of reality only when it breaks through its own nature as image. Not even trompe loeil painting, no matter how masterfully done, has been able to do precisely that: to let the world enter the pictorial, to let the pictorial form dissolve into substance, and to let this substance appear as if it were painted. It is here, where real wings stick to the painted surface, that we find the sublime-which Marin called "what is between the brimming over of measure, of form." Something that is already full, already completed to perfection in its own beautiful way, as is van der Broeck's astonishing painting, can still receive a supplement that is detachable yet integral to it, that is glued on but cannot quite be taken. And perhaps the sublimity that touches me today is not the tending to painting's limit attempted by van der Broeck's tableau, but the fact that, despite everything, I cannot help but hear the fluttering sound of the lost wings carrying the butterflies on their journey toward the light. 


\section{Acknowledgements}

I would like to thank the participants of the ERC program on "Elevated Minds" and the anonymous reader for the JHNA for their comments on this article, Stijn Bussels and Bram van Oostveldt for their effort in putting workshop and special issue together, and the NIAS for providing financial support.

Hanneke Grootenboer is Professor of the History of Art and the Head of the Ruskin School of Art at the University of Oxford. She is the author of The Rhetoric of Perspective: Realism and Illusionism in Seventeenth-Century Dutch Still Life Painting (Chicago: University of Chicago Press, 2005) and Treasuring the Gaze: Intimate Vision in Eighteenth-Century British Eye Miniatures (Chicago: University of (hicago Press, 2012), winner of the Kenshur Prize, 2014. She is currently completing a book to be titled The Pensive Image, which explores painting as a form of thinking. hanneke.grootenboer@hoa.ox.ac.uk

\section{List of Illustrations}

Fig. 1 Adriaen Coorte, Still Life with Medlars, ca. 1693-95, oil on paper on cardboard, 26.9 x 20.4 $\mathrm{cm}$. The Netherlands, Private Collection (artwork in the public domain)

Fig. 2 Still Life with Two Walnuts, 1702, oil on paper on cardboard, 10.9 x $15.6 \mathrm{~cm}$. Budapest, Szépmüvészeti Muzeum (artwork in the public domain; photo: () Budapest, Szépmüvészeti Muzeum)

Fig. 3 Adriaen Coorte, Still Life with Hazelnuts, 1696, oil on paper, 16.5 x $20 \mathrm{~cm}$. Oxford, Ashmolean Museum (artwork in the public domain; photo: (C) Ashmolean Museum, University of Oxford)

Fig. 4 Adriaen Coorte, Still Life with Shells, 1698, oil on paper, 17.2 x $22.2 \mathrm{~cm}$. United States, Private Collection (artwork in the public domain)

Fig. 5 Adriaen Coorte, Still Life with Shells, 1698, oil on paper on panel, 29.2 x $22.6 \mathrm{~cm}$. Private Collection (artwork in the public domain)

Fig. 6 Elias van den Broeck, Still Life with a Snake, ca. 1695, oil on canvas, 62 x 53 cm. Oxford, Ashmolean Museum (artwork in the public domain; photo: (C) Ashmolean Museum, University of Oxford)

\footnotetext{
1 "No object of Sense is sublime in itself; but only as far as I make it a symbol of some Idea. The circle is a beautiful figure in itself; it becomes sublime, when I contemplate eternity under that figure-The Beautiful is the perfection, the Sublime the suspension, of the comparing Power. Nothing not shapely (formosus: nam etiam musice suam habet formam) can be called beautiful: nothing that has a shape can be sublime except by metaphor ab occasione ad rem." Samuel Taylor Coleridge, "Unpublished Fragments on Aesthetics," ed. Thomas M. Raysor, Studies in Philosophy 22 (1925): 532-33.
} 
${ }^{2}$ See, for instance, Still Life with Apricots, Cherries and a Chestnut, 1685, Still Life with Berries, Medlars, and Grapes, 1686, or Still Life with Hanging Bunch of Grapes, Two Medlars and a Butterfly, 1687.

${ }^{3}$ Taco Dibbets, "Aardbeien, abrikozen, kruisbessen en perziken: vier stillevens van Adriaen Coorte," Bulletin van het Rijksmuseum 52, no. 2 (2004): 152-65. See also Quentin Buvelot, “The Still Lifes of Adriaen Coorte" in Adriaen Coorte, exh. cat. (Zwolle: Waanders Publishers, 2008). ${ }^{4}$ Paul Claudel, The Eye Listens, trans. Elsie Pell (New York: The Philosophical Library, 1950), 47-48.

${ }^{5}$ Simon Schama, The Embarrassment of Riches: An Interpretation of Dutch Culture in the Golden Age (New York and London: Harper Perennial, 2004).

${ }^{6}$ Conversely, Laurens Bol describes Coorte's work in terms of spiritualty and compares him to Spanish still-life painters such as Zubaran and Cotan. He examines Coorte's "lyrical realism" and defines his oeuvre as a whole as a pictorial eulogy of the light that reveals the forms of few objects on display. Laurens Bol, Adriaen Coorte: A Unique Late Seventeenth-Century Dutch Still Life Painter (Assen: Van Gorcum, 1978).

7 Thijs Weststeijn discusses van Hoogstraten's ideas on the "je ne sais quoi"of painting in great detail in his brilliant The Visible World: Samuel van Hoogstraten's Art Theory and the Legitimation of Painting in the Dutch Golden Age, trans. Beverley Jackson and Lynne Richards (Amsterdam: Amsterdam University Press, 2008), 154ff.

${ }^{8}$ For an exploration of still-life painting as phenomenology, see Wayne Martin, "Bubbles and Skulls: The Phenomenology of Self-Consciousness in Dutch Still Life Painting," in A Companion to Phenomenology and Existentialism, ed. Hubert L. Dreyfus and Mark A. Wrathall (London: Blackwell, 2006). http://dx.doi.org/10.1002/9780470996508.ch38

${ }^{9}$ Blaise Pascal, Pensées and Other Writings, trans. Honor Levi (Oxford: Oxford University Press, 2008), 67.

${ }^{10}$ Pascal, Pensées, 13. For an extended discussion of Pascal's use of linear perspective in relation to still-life painting, see Hanneke Groootenboer, The Rhetoric of Perspective: Realism and Illusionism in Dutch Seventeenth-Century Still Life Painting (Chicago: University of Chicago Press, 2005), in particular chapter 4.

${ }^{11}$ Quoted in Weststeijn, The Visible World, 157.

${ }^{12}$ André Félibien, Conversations on the Lives and Works of the Most Excellent Ancient and Modern Painters (1666), excerpted in Art in Theory 1648-1815: An Anthology of Changing Ideas, ed. Charles Harrison, Paul Wood, and Jason Gaiger (Oxford and Malden, Mass.: Blackwell Publishers, 2000), 221.

13 "Le merveilleux consiste d'ordinaire dans l'union de deux pensées \& de deux termes qui semblent contraires \& incompatible." Dominique Bouhours, Les entretiens d'Ariste et d'Eugène, Nouvelle Edition(Paris, 1741), 409.

${ }^{14}$ For a discussion as to the extent to which still-life paintings can conceptualize particular ideas, see Hanneke Grootenboer, "The Pensive Image: On Thought in Jan van Huysum's Still Life Paintings," Oxford Art Journal 34, no. 1 (March 2011): 13-30. http://dx.doi.org/10.1093/oxartj/kcr011

${ }^{15} \mathrm{I}$ have argued for still life's capacity to philosophize on the nature of representation in The Rhetoric of Perspective (see note 10 above). Following from that, my current project, to be titled The Pensive Image, proposes to consider (early modern) painting as a mode of thinking.

${ }^{16}$ My general understanding of the sublime has been most profoundly shaped by Louis Marin, Sublime Poussin, trans. Catherine Porter (Stanford, Calif.: Stanford University Press, 1999), 
and by Peter de Bolla, The Discourse of The Sublime: Readings in History, Aesthetics and the Subject (Blackwell, 1989). See also the excellent The Sublime: A Reader in British Eighteenth-Century Aesthetic Theory, ed. Peter de Bolla and Andrew Ashfield (Cambridge: Cambridge University Press, 1996).

${ }^{17}$ W. Rhys Roberts, Longinus on the Sublime: The Greek Text Edited After the Paris Manuscript (Cambridge: Cambridge University Press, 2011), 61.

${ }^{18}$ Louis Marin, “The Sublime in the 1670s: Something Indefinable, a 'Je Ne Sais Quoi'?” in Sublime Poussin, 213.

${ }^{19}$ This idea of an insight coming to us as if in a flash was later picked up by Walter Benjamin with his notion of the dialectical image, which he explored in literary miniatures that he labeled Denkbilder. For an application of still-life painting as Denkbild, see Hanneke Grootenboer, "Het Bedachtzame Beeld," De Witte Raaf 166 (November 2013): 1-2.

${ }^{20}$ Immanuel Kant, Critique of Judgement, trans. Werner Pluhar (Indianapolis: Cambridge Hackett, 1999), 106.

21 "Schilderye is een swijghende Poesye; de Poeyse daer en teghen is een sprekende Schilderye." Franciscus Junius, De schilder-konst der Oude (Middelburg: Zacharias Roman, 1641), 42. See also Weststeijn, The Visible World, 124.

${ }^{22}$ Junius, De schilder-konst, 42.

${ }^{23}$ Quoted in Weststeijn, The Visible World, 158.

${ }^{24}$ Jacques Derrida, The Truth in Painting (Chicago: University of Chicago Press, 1987), 127.

${ }^{25}$ Karin Leonhard, "Pictura's Fertile Field: Otto Marseus van Schrieck and the Genre of the Sottobosco Painting," Simiolus 34, no. 2 (2009-10): 95-118.

${ }^{26}$ In the introduction to the special issue of the Oxford Art Journal on early modern horror, Maria Loh distinguishes between the triumphant, masculinist discourse of the sublime celebrating the domination of the subject and the much less heroic process of internalizing of one's mortality as a way of knowing oneself, that she terms the "failed sublime." "Introduction: Early Modern Horror," Oxford Art Journal 34, no. 3 (2011): 321-33.

${ }^{27}$ My source for this section is Jacob Campo Weyerman, De levens-beschryvingen der Nederlandsche konst-schilders en konst-schilderessen, met een uytbreyding over de schilder-konst der ouden (The Hague: E. Boucquet et.al., 1729), 3:211-12.

${ }^{28}$ Weyerman writes that "dewijl de in fluweelgebroekte Sinjoors van die eerste Stad [Antwerpen] hem beschuldigden van de Vlindertjes geplakt and niet geschildert te hebben, daar die besnuyfde Hannekens niet overwoogen, dat de geplakte Vlindertjes schooner en natuurlijker zijn als geschilderden, dewijl zij niet alleen hun gantsche tekening behouden, maar ook langer dan de geschilderden duuren." Weyerman, Levens-beschryvingen, 3:211.

${ }^{29}$ Both Weyerman and Houbraken mention that van den Broeck had the use of a flower garden (Bloemtuyn or Bloemhof) close to where he lived near the Molenpad outside of the Utrechtse Poort in Amsterdam. Arnold Houbraken, De groote schouburgh der Nederlantsche konstschilders en schilderessen (Amsterdam: B. M. Israël, 1976), 2:379.

\section{Bibliography}

Bol, Laurens. Adriaen Coorte: A Unique Late Seventeenth-Century Dutch Still Life Painter. Assen: Van Gorcum, 1978.

Bolla, Peter de. The Discourse of The Sublime: Readings in History, Aesthetics and the Subject. Os- 
ford: Blackwell, 1989.

Bouhours, Dominique. Les entretiens d'Ariste et d'Eugène, Nouvelle Edition.Paris, 1741.

Buvelot, Quentin. “The Still Lifes of Adriaen Coorte.” In Adriaen Coorte. Exh. cat. Zwolle: Waanders Publishers, 2008.

Claudel, Paul. The Eye Listens. New York: The Philosophical Library, 1950.

Derrida, Jacques. The Truth in Painting. Chicago: University of Chicago Press, 1987.

Dibbets, Taco. "Aardbeien, abrikozen, kruisbessen en perziken: vier stillevens van Adriaen Coorte." Bulletin van het Rijksmuseum 52, no. 2 (2004): 152-65.

Félibien, André. "Conversations on the Lives and Works of the Most Excellent Ancient and Modern Painters (1666). Excerpted in Art in Theory 1648-1815: An Anthology of Changing Ideas. Edited by Charles Harrison, Paul Wood, and Jason Gaiger. Oxford and Malden, Mass.: Blackwell Publishers, 2000 .

Grootenboer, Hanneke. "Het Bedachtzame Beeld.” De Witte Raaf 166 (November 2013): 1-2.

Grootenboer, Hanneke. “The Pensive Image: On Thought in Jan van Huysum's Still Life Paintings." Oxford Art Journal 34, no. 1 (March 2011): 13-30. http://dx.doi.org/10.1093/oxartj/kcr011

Grootenboer, Hanneke. The Rhetoric of Perspective: Realism and Illusionism in Dutch Seventeenth-Century Still Life Painting. Chicago: University of Chicago Press, 2005.

Houbraken, Arnold. De groote schouburgh der Nederlantsche konstschilders en schilderessen. 3 vols. Amsterdam: B. M. Israël, 1976.

Junius, Franciscus. De schilder-konst der Oude. Middelburg: Zacharias Roman, 1641.

Kant, Immanuel. Critique of Judgement. Translated by Werner Pluhar. Indianapolis: Cambridge Hackett, 1999.

Leonhard, Karin. "Pictura's Fertile Field: Otto Marseus van Schrieck and the Genre of the Sottobosco Painting." Simiolus 34, no. 2 (2009-10): 95-118.

Marin, Louis. Sublime Poussin. Translated by Catherine Porter. Stanford, Calif.: Stanford University Press, 1999.

Martin, Wayne. "Bubbles and Skulls: The Phenomenology of Self-Consciousness in Dutch Still Life Painting." In A Companion to Phenomenology and Existentialism, edited by $\mathrm{Hu}-$ bert L. Dreyfus and Mark A. Wrathall, 559-85 London: Blackwell, 2006. http://dx.doi. org/10.1002/9780470996508.ch38 
Pascal, Blaise. Pensées and Other Writings. Translated by Honor Levi. Oxford: Oxford Univeristy Press, 2008.

Roberts, W. Rhys. Longinus on the Sublime: The Greek Text Edited After the Paris Manuscript. Cambridge: Cambridge University Press, 2011.

Schama, Simon. The Embarrassment of Riches: An Interpretation of Dutch Culture in the Golden Age. New York: Harper Perennial, 2004.

Weststeijn, Thijs. The Visible World: Samuel van Hoogstraten's Art Theory and the Legitimation of Painting in the Dutch Golden Age. Translated by Beverley Jackson and Lynne Richards. Amsterdam: Amsterdam University Press, 2008.

Weyerman, Jacob Campo. De levens-beschryvingen der Nederlandsche konst-schilders en konst-schilderessen, met een uytbreyding over de schilder-konst der ouden. 4 vols, The Hague: E. Boucquet et.al., 1729.

\section{Recommended Citation:}

Hanneke Grootenboer, "Sublime Still Life: On Adriaen Coorte, Elias van den Broeck, and the Je ne sais quoi of Painting," JHNA 8:2 (Summer 2016), D0I: 10.5092/jhna.2016.8.2.10 